Borichenko 0., Cherniavskyi $\mathbf{A}$.

\title{
IDENTIFICATION OF OBJECTS PRIORITY FOR CONDUCTING ENERGY MONITORING
}

Об’єктом дослідження є система енергетичного моніторингу. Для досягнення високого рівня енергоефективності на будь-якому підприємстві необхідно проводити періодичну оцінку рівня результативності енергозберігаючої діяльності, тобто проводити енергетичний моніторинг. Одним з найбільш проблемних місиь при створенні систем енергетичного моніторингу є визначення пріоритетності об'єктів, для яких можливо та доцільно проводити моніторинг. При визначенні об'єктів, для яких є доцільним створення системи енергетичного моніторингу, слід враховувати основні вимоги, яким мають відповідати такі об'єкти. Серед таких вимог: розташування об'єктів в одному або суміжному приміщеннях, єдиний технологічний процес та керування цими об'єктами невеликої кількості операторів. Відповідно до зазначених вимог в роботі був запропонований алгоритм вибору об'єктів для створення системи енергетичного моніторингу. На периому етапі все обладнання підприємства має бути розділено на невелику кількість груп за технологічним принципом. Наступним кроком є побудова балансів споживання енергї окремо для кожного з технологічних процесів виробництва всіх видів продукції підприємства. Для складання балансів енергоспоживання може бути застосована методика побудови оптимальних розрахункових моделей енергобалансів. На основі отриманих розрахункових значень споживання енергї на виробництво кожного виду продукцї може бути здійснений розподіл обладнання на більш дрібні групи, виходячи з двох критеріїв. До таких критеріӥв відносяться місие розташування обладнання та їх живлення енергією від одних і тих же силових пунктів. Отримані групи обладнання являють собою попередні об'єкти, однак це не означає, що для таких об'єктів є доцільним створення системи енергетичного моніторингу. В роботі запропоновано вирішення додаткових задач, зокрема:

- визначення складу чинників, які впливають на обсяги енергоспоживання;

- доцільність встановлення додаткових приладів обліку енергоспоживання, виробництва продукцї та іниих параметрів;

- оцінка грошових витрат на створення систем;

- оцінка потенщіалу енергозбереження;

- фінансовий аналіз доцільності створення систем.

Завдяки цьому забезпечується можливість обгрунтовано визначити об'єкти, для яких є технічно можливим і фінансово доцільним створення системи енергетичного моніторингу.

Ключові слова: впровадження системи енергетичного моніторингу, рівень енергоефективності підприємства, використання енергоресурсів.

\section{Introduction}

Increasing the level of energy efficiency of the enterprise is one of the main tasks of modern production. A significant portion of the cost of production is the component for the used energy resources. Despite the constant increase in tariffs for fuel and energy resources, it is advisable to analyze and control energy consumption and maximize its reduction in order to increase the competitiveness of goods in the domestic and international markets.

The solution of these problems, first of all, should begin with the improvement of enterprise management systems, especially in optimizing energy consumption management systems through the introduction of energy management systems (EnMS) in enterprises, both on the basis of international and national energy management standards [1, 2].

Regardless of which standard is used by enterprises in implementing the EnMSs for its effective functioning, it is necessary to periodically assess (monitor) the level of EnMS efficiency and, based on its results, develop and implement a set of preventive and corrective measures to increase this level. One of the important tasks that need to be addressed in the process of energy monitoring is the choice of the priority of monitoring objects.

According to the recommendations of the international standard ISO 50001:2011 [1], the priority of monitoring objects is established on the basis of the energy capacity of the element (the most energy-intensive facility is determined, in it - the most energy-intensive site in which the most energy-intensive facility is located).

However, the ownership of an installation in an energyintensive one is by no means always a sufficient condition for the element to be monitored primarily (before other elements, less energy-intensive). This is due both to financial constraints and the economic feasibility of implementing such monitoring system, as well as to the technical feasibility of its implementation for a particular facility.

Therefore, it is urgent to develop a mechanism for determining the priority of facilities that are technically possible and economically feasible to include an energy monitoring system. 


\section{The object of research and its technological audit}

The object of research is the energy monitoring system. Given the fact that modern concepts of building EnMS are based on the use of a process approach, it is logical to decompose this activity into simpler processes and monitor these processes. In the general case, a «process» can be defined as «a set of interrelated or interacting activities that convert something at the input to the output». In this case, the process can be [3]:

- planning process (organization, analysis, control ...), implementation of activities;

- operating of individual installations;

- operating of the technological line, section, shop;

- operating of the enterprise as a whole and the like.

At each point in time, the level of performance of the facility in the field of energy management (as a set of individual processes) is characterized by a set of indicators that, under the influence of external and internal factors, are constantly changing and taking definite values. The most important is the EnMS state, in which it functions in accordance with specified criteria, and its indicators are within acceptable limits. Violation of the permissible limits of the indicators of EnMS energy performance can lead to a violation of its normal functioning. Therefore, any EnMS requires periodic assessment of the level of effectiveness of its functioning, that is, in carrying out energy monitoring.

Energy monitoring in this article, as in [3] is observation, tracking, analysis and evaluation of the performance of the facility in the field of energy management for the selected set of performance indicators. As performance indicators can be used as single absolute and/or relative indicators, as well as more complex integral indicators or even single and multifactor mathematical function [3, 4].

The main goal of energy monitoring is assisting the company's top management in developing optimal management decisions and developing recommendations for improving the efficiency of fuel and energy usage in the enterprise by conducting continuous monitoring and assessing the state of fuel and energy consumption. As well as the level of use of the energy saving potential, sources of losses and volumes of irrational use of fuel and energy resources by production and support units, technological processes and individual consumers, the results of implementing energy-saving measures.

Traditionally, energy monitoring systems are created and used for individual installations, aggregates and small groups of them, and for whole technological processes.

At any production facility, the number of process installations is measured in hundreds or even thousands. For the implementation of energy monitoring system, there is potentially a need to build hundreds of local systems, which is associated with significant time and costs. And the expediency of these costs is far from always obvious.

The choice of individual process units, their groups or technological processes for which it is possible and appropriate to create local energy monitoring systems, is a rather complex task. The solution of this task should be carried out «individually» for each production facility.

Determining local technological facilities that can be and is feasible to cover the energy monitoring system [5], first of all, it is suggested to take into account such requirements that these objects must meet:
- equipment to which the monitoring system is intended to be distributed should be located in one or in adjacent production facilities so that there is the possibility of organizing a unified record of its total energy consumption;

- such equipment must be united among themselves by a single technological process, that is, shared to produce the same type of product or several of its types;

- such equipment should be managed by a small number of operators, so that the human factor's influence on the process of energy consumption is minimal.

\section{The aim and objectives of research}

The aim of research is creation of methodological bases for selection of objects for which it is advisable to extend an energy monitoring system at an enterprise.

To achieve this aim, it is necessary to perform the following tasks:

1. To formulate the basic requirements for objects for which it is appropriate to extend the energy monitoring system.

2. To propose a general algorithm for solving the problem of the choice of technological objects, for which it is advisable to extend an energy monitoring system at an enterprise.

3. To identify and solve additional tasks in terms of the feasibility of establishing energy monitoring system for pre-defined equipment groups.

\section{Research of existing solutions of the problem}

In [5], the authors propose an original concept for constructing integrated systems for monitoring the efficiency of the use of electrical energy at production and economic facilities. However, this concept only applies to the consumption of electrical energy, which, unlike fuel consumption or thermal energy, may not be a significant use in the total consumption of fuel and energy resources.

The publications [6-9] describe world trends in the construction and application of energy monitoring systems, as well as systems for operational control of energy efficiency. Such systems have proved themselves in foreign practice as an effective tool for the operational control of the efficiency of the use of fuel and energy at local technological facilities. However, in these works there is no definite approach to the choice of objects to which it is advisable to extend such systems.

The papers [10-12] are devoted to the construction of energy saving monitoring systems in EnMSs, but there is an unresolved issue of justifying the choice of facilities for the creation of such systems.

A description of the methodology for constructing systems for operational control of energy efficiency is given in [13]. Despite the fact that in this work the issues of selecting monitoring objects are not fully disclosed, it is proposed to establish energy accounting centers for the most energy-intensive consumers.

The above publications on building energy monitoring systems do not even address the choice of priorities for energy monitoring facilities, or the issue has been described in a rather fragmented manner. Or the proposed approach is in determination of only the most priority element. 
However, in practice, the need arises not for the definition of the most priority element, but for the compilation of all elements according to the priority level. To solve this problem, it is proposed in [3,14] to use a multicriteria approach using, for example, the Analytic Hierarchy Process, which algorithm is described in detail in [15].

\section{Methods of research}

Taking into account the above main requirements, the general algorithm for solving the problem of selecting process objects for building a system of energy monitoring of local objects in any enterprise can be as follows.

At the first stage all the main and auxiliary equipment of the enterprise should be divided into a certain, relatively small number of groups. It is most expedient to carry out such a distribution on a technological basis. That is, the existing technological equipment needs to be distributed among the technological processes of production of all types of the enterprise's products.

For this purpose, first of all, it is necessary to draw up diagrams of the corresponding technological processes that should reflect the sequence of individual operations and the relationship between them. And also information about the equipment on which these operations are performed, indicating the types of energy resources, while consuming.

The next step in the solution of the problem should be to build energy consumption balances separately for each of the technological processes of production of all types of enterprise products. To do this, it is possible to apply the technique, described in detail in DSTU 4714:2007 [16]. In addition, to compile balances of consumption of electrical energy in the production processes of each type of products, the method of constructing optimal design models of the electric balance, given in [17], can be applied.

On the basis of the constructed energy consumption balances and the generated technological schemes, the actual volumes of energy consumption for the previous periods in the enterprise can be reasonably distributed among all types of products. Thus, it is possible to obtain pseudo-statistical data on energy consumption for the production of each type of product, which are necessary at the subsequent stages of identifying local technological facilities for the creation of an energy monitoring system in the enterprise.

The next step in solving this problem should be to separate the main and auxiliary equipment, referred to the technological process of production of each type of product, into smaller groups. Such further grouping of equipment should be carried out on the basis of two criteria.

The first of these criteria should be the location of the relevant equipment in those or other buildings, structures or production facilities. Obviously, equipment belonging to the same building or structure, or in one or in adjacent premises, should be included in one group.

The second criterion for further grouping of the technological equipment of the enterprise should be schemes of internal power supply of the corresponding buildings, facilities and production facilities. That is, equipment located in the same or in adjacent premises can (and should) be further distributed to even smaller groups, which power is supplied by electricity from the same power points.

The resulting groups of technological equipment obtained as a result of this additional distribution represent the previous objects for which an energy monitoring system can physically be built at the enterprise. However, this does not mean that the creation of an energy monitoring system for these objects is advisable.

So, for the final solution of the considered task, it is necessary to further analyze the pre-installed equipment groups from the point of view of the feasibility of their coverage by the energy monitoring system.

Such analysis, in turn, requires the solution of a number of additional tasks. The main of these tasks are:

- determination of the composition of factors (process parameters, external conditions, etc.) that affect the energy consumption of each of the predefined equipment groups;

- determination of additional meters for energy consumption, production, as well as parameters characterizing the operating conditions necessary for building an energy monitoring system for each of the equipment groups; - estimation of monetary costs for the construction and operation of such energy monitoring system;

- estimation of the energy saving potential, which will be due to the creation of an energy monitoring system covering each considered group of equipment; - financial analysis of the feasibility of establishing an energy monitoring system for pre-defined equipment groups.

\section{Research results}

The algorithm for selecting the objects for which it is necessary to distribute the energy monitoring system is illustrated by the example of the smelting section of one of the non-ferrous metallurgy enterprises listed below.

For the specified site, using various methods, several options are chosen for selecting objects for building the energy monitoring system. In view of the limited volume of the publication, let's consider only the use of $\mathrm{ABC}$ analysis for solving the problem [18]. This analysis is based on the grouping of objects depending on the significance and the specific characteristics. First it is necessary to select the objects that would be combined with a common feature. For example, this can be the amount of energy consumption of each type of equipment in a separate production unit. In the future, the total value of energy consumption for the production unit as a whole is calculated:

$$
W_{t o t}=W_{1}+W_{2}+\ldots+W_{n},
$$

where $W_{1}, W_{2}, \ldots, W_{n}$ - annual power consumption of a separate $n$-th sample object; $n$ - the corresponding number of the sample object.

Substituting the corresponding values in the formula (1), let's obtain:

$$
W_{\text {tot }}=1166760+207424+\ldots+1248=1978922.93 \mathrm{kWh} \text {. }
$$

Then, for each sample object, its share of energy consumption in the total energy consumption of the production unit is determined, as well as the increasing share for each object, respectively, according to the formulas:

$$
\begin{aligned}
& K_{p}=\frac{W_{p}}{W_{t o t}} \cdot 100 ; \\
& K_{i}=K_{n}+K_{n+1} .
\end{aligned}
$$


Let's substitute the values in formulas (2) and (3) and, accordingly, we obtain:

$$
\begin{aligned}
& K_{p}=\frac{1166760}{1978922.93} \cdot 100=58.96, \\
& K_{i}=58.96+10.48=69.44 .
\end{aligned}
$$

Having determined for each object of the production unit the value of its share by the growing total, the values of the calculated $K_{i}$ are analyzed and the grouping of these objects is performed as follows:

- sampling objects for which the total share approaches $80 \%$, this is the lower limit of group A. The upper boundary of group $\mathrm{A}$ is the first position in the list of sample objects of the corresponding subdivision;

- the sample object for which the total share approaches

$95 \%$, this is the lower bound of group B;

- all other sampling objects for which the total share

is more than $95 \%$ belong to the group $\mathrm{C}$.

The results of calculations with the help of $\mathrm{ABC}$ analysis for determining the objects for building the energy monitoring system are given in Table 1.

\begin{tabular}{|c|c|c|c|c|c|}
\hline No. & $\begin{array}{l}\text { Name of } \\
\text { energy-consuming } \\
\text { equipment }\end{array}$ & $\begin{array}{c}\text { Annual } \\
\text { power con- } \\
\text { sumption, } \\
\text { kWh }\end{array}$ & $\begin{array}{c}\text { Share of } \\
\text { energy } \\
\text { consump- } \\
\text { tion, \% }\end{array}$ & $\begin{array}{l}\text { Increa- } \\
\text { sing } \\
\text { total }\end{array}$ & $\begin{array}{c}\mathrm{ABC} \\
\text { analysis } \\
\text { group }\end{array}$ \\
\hline 1 & $\begin{array}{l}\text { Induction furnace, } \\
\text { crucible }\end{array}$ & 1166760.00 & 58.96 & 58.96 & A \\
\hline 2 & $\begin{array}{l}\text { Steam sterilizer } \\
\text { No. 1, 2, 3, } 4\end{array}$ & 207424.00 & 10.48 & 69.44 & A \\
\hline 3 & $\begin{array}{l}\text { Chamber drying } \\
\text { No. } 1,2\end{array}$ & 105737.63 & 5.34 & 74.78 & A \\
\hline 4 & Lighting: & 101860.74 & 5.15 & 79.93 & A \\
\hline 5 & Electric heaters & 66672.00 & 3.37 & 83.30 & B \\
\hline 6 & $\begin{array}{l}\text { Catalytic after- } \\
\text { burner }\end{array}$ & 56000.00 & 2.83 & 86.13 & B \\
\hline 7 & $\begin{array}{l}\text { Pump of circulating } \\
\text { water supply No. } 1\end{array}$ & 51393.00 & 2.60 & 88.73 & B \\
\hline 8 & $\begin{array}{l}\text { Vacuum water ring } \\
\text { pump }\end{array}$ & 33408.00 & 1.69 & 90.42 & B \\
\hline 9 & Prefoaming device & 25928.00 & 1.31 & 91.73 & B \\
\hline 10 & \begin{tabular}{|l|} 
Exhaust ventilation \\
V-20, V-21
\end{tabular} & 17779.20 & 0.90 & 92.62 & B \\
\hline 11 & $\begin{array}{l}\text { Shot blasting } \\
\text { machine }\end{array}$ & 17472.00 & 0.88 & 93.51 & B \\
\hline 12 & Cooler & 16704.00 & 0.84 & 94.35 & B \\
\hline 13 & $\begin{array}{l}\text { Exhaust ventilation } \\
\text { of the vibrating } \\
\text { screen }\end{array}$ & 16704.00 & 0.84 & 95.20 & c \\
\hline 14 & $\begin{array}{l}\text { Supply ventilation } \\
\text { PU-1 }\end{array}$ & 16668.00 & 0.84 & 96.04 & C \\
\hline 15 & $\begin{array}{l}\text { Workbench for } \\
\text { collecting model } \\
\text { blocks }\end{array}$ & 15001.20 & 0.76 & 96.80 & C \\
\hline 16 & Roller table & 14699.52 & 0.74 & 97.54 & c \\
\hline 17 & Fan & 11136.00 & 0.56 & 98.10 & c \\
\hline 18 & $\begin{array}{l}\text { Supply ventilation } \\
\text { PU-2 }\end{array}$ & 10000.80 & 0.51 & 98.61 & c \\
\hline
\end{tabular}

Results of calculations using ABC analysis
As can be seen from Table 1, according to the calculation results, Group A includes four objects that have the largest share in the total power consumption of the entire site, therefore, it is for these objects, first of all, that it is necessary to build systems for operational control of energy consumption.

For example, in the subsequent calculations, let's consider only the crucible furnace, located at the first position in group $\mathrm{A}$.

The next step is determination of the composition of the factors that influence the change in the energy consumption of the crucible furnace. For this purpose, expert assessment methods are used, which are described in detail in [19]. The group is formed from the service and production personnel of the enterprise. To determine which factors most influence the change in the energy consumption of the crucible furnace, experts are asked to assess the influence of the corresponding factor on the linguistic scale.

After processing the results of a survey of experts using a fuzzy logic apparatus [19] it is found that the most significant factors that affect the change in the volumes of electric consumption of the crucible furnace are:

- amount of melted metal, tonnes;

- melting temperature of metal, ${ }^{\circ} \mathrm{C}$.

In the future, to build an energy monitoring system for each of the groups of equipment, it is necessary to determine additional meters for energy consumption, production, as well as parameters characterizing the operating conditions, and to estimate the monetary costs for the construction and operation of such an energy monitoring system.

The cost of building an energy monitoring system includes the costs of acquiring and installing meters for the consumption of electrical energy, as well as the necessary additional measuring devices of the relevant process parameters. The cost of devices for measurement is $C_{d e v}=7500$ c.u. Moreover, the cost of training of personnel is $C_{t r}=2000 \mathrm{c} . \mathrm{u}$. The total cost of building such system is 9500 c.u.

The costs of the energy monitoring system include the costs of data collection and processing, measurement and annuity costs.

The cost of measuring data is determined by the formula:

$$
C_{m}=T_{m} \cdot n_{w} \cdot \bar{S} \cdot k_{m},
$$

where $T_{m}$ - the time required for one measurement, hour. $\bar{S}$ - average salary of the employee, c. u./hour; $n_{w}-$ number of workers performing measurements; $k_{m}$ - number of measurements per month.

Let's assume that $T_{m}=0.5$ hour, $n_{w}=1, \bar{S}=25$ c.u./hour, $k_{m}=22$ (one measurement of each working day). Let's substitute the corresponding values in the formula (4) and calculate the costs for measuring the indicators necessary for the functioning of the energy monitoring system:

$$
C_{m}=0.5 \cdot 1 \cdot 25 \cdot 22=275 \text { c. u. }
$$

The costs of data collection can be calculated by the formula:

$$
C_{c}=T_{c} \cdot n_{w} \cdot \bar{S} \cdot k_{m}
$$

where $T_{c}$ - the time required to collect information for the relevant period. 
Let's assume that the $T_{c}=1$ hour, $n_{w}=1, \bar{S}=25$ c.u. $/$ hour, $k_{m}=22$. Let's substitute the corresponding values in the formula (5) and determine the costs of data collection:

$$
C_{c}=1 \cdot 1 \cdot 25 \cdot 22=550 \mathrm{c} . \mathrm{u} \text {. }
$$

The costs of data processing are determined by the formula:

$$
C_{d . p}=T_{d . p} \cdot n_{w} \cdot \bar{S} \cdot k_{d . p},
$$

where $T_{\text {d.p. }}$ - the time required to data processing for the relevant period.

Let's assume that $T_{d . p}=1$ hour, $n_{w}=1, \bar{S}=25$ c.u./hour, $k_{m}=22$ (periodicity of data processing per month). Let's substitute the corresponding values in the formula (6) and calculate the costs of processing the data necessary for the functioning of the energy monitoring system:

$$
B_{d . p}=1 \cdot 1 \cdot 25 \cdot 22=550 \text { c. u. }
$$

The total costs for the operation of the energy monitoring system are 1375 c.u.

It is also necessary to take into account depreciation charges. To do this, it is necessary to calculate the annuity:

$$
A=k \cdot C_{d e v},
$$

where $k$ - the annuity coefficient, which is calculated by the formula:

$$
k=\frac{i \cdot(1+i)^{n}}{(1+i)^{n}-1},
$$

where $i$ - the discount rate; $n$ - the number of periods during which an annuity is valid.

Let's accept discount rates equal to $22 \%$ and the number of periods set to 10 years (let's accept for the lifetime of the measuring devices).

Let's substitute the corresponding values in the formula (8) and calculate the annuity coefficient:

$$
K=\frac{0.22 / 10 \cdot(1+0.22 / 10)^{10}}{(1+0.22 / 10)^{10}-1}=0.11
$$

Thus, the annual depreciation charges is determined by the formula (7) and is:

$$
A=0.11 \cdot 9500=1045 \text { c. u. }
$$

In the future, it is necessary to assess the potential for energy saving, which will take place through the creation of energy monitoring systems for the selected facility. Electricity savings as a result of the construction of such systems by international experience are 5-10\% of the cost of electricity for the year [13]. For a crucible furnace, the energy saving of electricity is 12737 c.u.

Taking into account the calculated costs for building and functioning of energy monitoring systems, as well as the potential for energy saving, it is necessary to analyze financially the feasibility of creating such systems for predefined equipment groups.

Decision-making on the financial feasibility of establishing operational control systems for the relevant equipment group should be based on the definition of the following economic criteria, namely [20]:

- simple and dynamic payback period;

- net present value;

- internal rate of return.

\section{SWOT analysis of research results}

Strengths. In contrast to existing approaches, energy monitoring objects are determined not only by the level of energy intensity, but also taking into account the technical feasibility and economic feasibility of their coverage by the energy monitoring system.

Weaknesses. The main disadvantage of the proposed approach to the selection of energy monitoring objects is the complexity of calculation and the need to use application software products. And also an increase in labor costs for the selection of monitoring objects in the construction of an energy monitoring system.

Opportunities. Opportunities for further research are reducing the cost of building a monitoring system and, at the same time, increase the number of monitoring facilities, taking into account the technical feasibility and economic feasibility of their coverage by the energy monitoring system.

Threats. The variability in the structure of production, as well as the modernization of the enterprise, will require re-evaluation of the practicability of the implemented energy monitoring system. And this, in turn, will require additional financial costs to change the configuration of the monitoring system.

\section{Conclusions}

1. It is shown that when determining the facilities for which it is reasonable and technically possible to create systems for operational control of energy efficiency, it is necessary to take into account the basic requirements that such facilities should meet. Among such requirements: location of objects in one or adjacent production premises, a single technological process and the management of these objects of a small number of operators.

2. The algorithm of selection of objects, which should cover the system of energy monitoring, is proposed in the work. First, all equipment of the enterprise should be divided into a small number of groups on a technological basis. Secondly, to build energy consumption balances separately for each of the technological processes of production of all types of enterprise products. Based on the calculated values of energy consumption for the production of each type of product, equipment can be distributed into smaller groups based on two criteria. These criteria include the location of equipment and their power supply from the same power points. The resulting equipment groups are the previous objects, but this does not mean that an energy monitoring system is appropriate for such facilities.

3. To provide an opportunity to reasonably determine the facilities that are technically possible and financially feasible to cover the energy monitoring system, a solution is proposed for additional tasks. Namely:

- determination of the composition of factors affecting the energy consumption of each of the specific groups of equipment; 
- justification of the feasibility of installing additional energy consumption meters, production and other parameters;

- estimation of monetary expenses for creation of control systems;

- estimation of energy saving potential and financial analysis of the feasibility of creating systems.

\section{References}

1. ISO 50001:2011. Energy management systems. Requirements with guidance for use. ISO, 2011.

2. Vnedrenie sistemy energeticheskogo menedzhmenta na baze standarta ISO 50001:2011: Putevoditel' dlya spetsialistov kompaniy i predpriyatiy / Inshekov, E. et al. Kyiv: Proekt «Energoeffektivnaya i napravlennaya na umen'shenie izmeneniya klimata modernizatsiya promyshlennosti v Donetskoy oblasti», 2014. 36 p.

3. Rozen V. P., Cherniavskyi A. V. Enerhetychnyi monitorynh yak skladova chastyna systemy enerhetychnoho menedzhmentu // Ekonomichna bezpeka derzhavy: stratehiia, enerhetyka, informatsiini tekhnolohii: monograph / ed. by Lukianenko S. O., Karaievoi N. V. Kyiv: Vydavnytstvo OOO «Iurka Liubchenka», 2014. 468 p.

4. DSTU ISO 50006:2014. Systemy enerhetychnoho menedzhmentu. Vymiriuvannia rivnia dosiahnutoi enerhoefektyvnosti z vykorystanniam bazovykh rivniv enerhospozhyvannia ta pokaznykiv enerhoefektyvnosti. Zahalni polozhennia i nastanova». Kyiv: Derzhspozhyvstandart Ukrainy, 2016. 56 p.

5. Nakhodov V. F., Borychenko O. V. Kontseptsiia pobudovy intehrovanykh system kontroliu efektyvnosti vykorystannia elektrychnoi enerhii na vyrobnycho-hospodarskykh obiektakh // Enerhetyka: ekonomika, tekhnolohii, ekolohiia. 2013. No. 1. P. 72-79.

6. Pooley J. Quick Start Guide to Energy Monitoring \& Targeting (M\&T) // Effective Energy Management Guide, 2005. URL: http://www.oursouthwest.com/eemg/notices/effective-energymgt-mandtguide.pdf

7. Computer Based Monitoring And Targeting On A Hot Rolling Mill // Energy Effiiciency Enquiries Bureau, ETSU, Harwell, Oxfordshire, 0X11. Best Practice Programme, 1992. 26 p.

8. Waste avoidance methods // Energy Effiiciency Office. Best Practice Programme. Fuel Efficiency Booklet 13. Crown copyright, 1995. $18 \mathrm{p}$.

9. Monitoring and Targeting in large companies // Energy Effiiciency Enquiries Bureau, ETSU, Harwell, Oxfordshire, 0X11. Good Practice Guide 112, 1998. 45 p.
10. Jones P. Getting started with Monitoring \& Targeting $(\mathrm{M} \& \mathrm{~T}) / /$ Fundamental Series. 2004. No. 7. P. 29-32.

11. Khayd D., Loskutov A. V. Tselevoy energeticheskiy monitoring v sisteme energeticheskogo menedzhmenta // Promyshlennaya energetika. 1998. No. 4. P. 2-4.

12. Loskutov A. Monitoring and Targeting in Russian Industry // Seminar «Energy management: Low cost energy saving Techniques». Sofia, 1997.

13. Prakhovnyk A. V., Trapp H. R. Kontrol i normalizatsiia enerhospozhyvannia. Upravlinnia enerhovykorystanniam. Kyiv: Alians za zberezhennia enerhii, 2001. P. 387-398.

14. Analitychne zabezpechennia enerhetychnoho monitorynhu / Cherniavskyi A. V. et al. // Energosberezhenie. Energetika. Energoaudi. 2015. Vol. 2, No. 133. P. 41-45.

15. Primenenie metoda analiza ierarkhiy pri vybore energoeffektivnogo oborudovaniya i tekhnologiy / Rozen V. P. et al. // Pratsi Mizhnarodnoho enerhoekolohichnoho konhresu «Enerhetyka. Ekolohiia. Liudyn». Kyiv, 2003. P. 166-171.

16. DSTU 4714:2007. Enerhozberezhennia. Palyvno-enerhetychni balansy promyslovykh pidpryiemstv. Metodyka pobudovy ta analizu. Kyiv: Derzhspozhyvstandart Ukrainy, 2007. 33 p.

17. Nakhodov V. F., Borychenko O. V. Pobudova optymalnykh rozrakhunkovykh modelei elektrobalansiv vyrobnycho-hospodarskykh obiektiv // Promyslova elektroenerhetyka ta elektrotekhnika. 2010. No. 6. P. $47-51$.

18. A Complete Guide to ABC Analysis in Customer Segmentation and Inventory. URL: https://www.cleverism.com/completeguide-abc-analysis-customer-segmentation-inventory/

19. Kompleksnyi pidkhid do vyznachennia skladu chynnykiv, shcho vplyvaiut na velychynu enerhospozhyvannia pry vprovadzhenni system operatyvnoho kontroliu enerhoefektyvnosti / Nakhodov V. F. et al. // Enerhetyka: ekonomika, tekhnolohii, ekolohiia. 2014. No. 2. P. 68-79.

20. 20. Tarasiuk H. M. Upravlinnia proektamy: textbook. Kyiv: Karavela, 2006. 320 p.

Borichenko Olena, PhD, Associate Professor, Department of Power Supply, National Technical University of Ukrain «Igor Sikorsky Kyiv Polytechnic Institue»,Ukraine, e-mail: borichenko olena@ukr.net, ORCID: http://orcid.org/0000-0002-6127-2945

Cherniavskyi Anatolii, PhD, Associate Professor, Department of Power Supply, National Technical University of Ukrain «Igor Sikorsky Kyiv Polytechnic Institue»,Ukraine, e-mail: canatoliy1976@gmail.com, ORCID: http://orcid.org/0000-0003-2858-824 